\title{
Analysis of deposition of heavy metal dust on the leaves of few selected tree species in Kanchipuram town, Tamil Nadu, India
}

\author{
Sumathi Ramesh* \\ Department of Civil \& Structural Engineering, Sri Chandrasekharendra Saraswathi Viswa \\ Mahavidyalaya, Enathur, Kanchipuram- 631561 (Tamil Nadu), India

\section{Sriram Gopalsamy} \\ Department of Mechanical Engineering, Sri Chandrasekharendra Saraswathi Viswa \\ Mahavidyalaya, Enathur, Kanchipuram- 631561 (Tamil Nadu), India \\ *Corresponding author. Email: sumathiram72@gmail.com
}

\section{Article Info}

https://doi.org/10.31018/ jans.v13i3.2739

Received: June 1, 2021

Revised: August 25, 2021

Accepted: September 3, 2021

\section{How to Cite}

Ramesh, S. and Gopalsamy, S. (2021). Analysis of deposition of heavy metal dust on the leaves of few selected tree species in Kanchipuram town, Tamil Nadu, India. Journal of Applied and Natural Science, 13(3), 1011 - 1019. https://doi.org/10.31018/ jans.v13i3.2739

\begin{abstract}
Biomonitoring of heavy metals is one of the economic methods to identify and improve the quality of air. The aim of this work was to identify the concentration of nine heavy metals viz. $\mathrm{Fe}, \mathrm{Pb}, \mathrm{Cu}, \mathrm{Zn}, \mathrm{Al}, \mathrm{Cd}, \mathrm{As}, \mathrm{Cr}$ and $\mathrm{Mn}$ in the ambient air deposited on the leaves of five tree species such as Saraca asoca, Terminalia catappa, Syzygium cumini, Ficus religiosa and Pongamia glabra collected from six sites such as Pallavarmedu (Site I), CSI hospital (Site II), Moongilmandapam (Site III), Collectrate (Site IV), Near Cancer Institute (Site V) and VellaGate (Site VI) of the Kanchipuram town of TamilNadu State, in the months of February - March 2019. Even with some differences in the concentration of nine heavy metals on the species, few were identified with significant correlation, suggesting that these pollutants were emitted from similar sources. The deposition of iron $(235.53 \mathrm{mg} / \mathrm{kg})$ and aluminium $(157.91 \mathrm{mg} / \mathrm{kg})$ were higher on the leaves of S.asoca compared with other species. The metals such as Cu, Cd, $\mathrm{As}, \mathrm{Pb}$ and $\mathrm{Cr}$ were nil and not detected on the leaves, but $\mathrm{Pb}$ concentration was high $(185.79 \mathrm{mg} / \mathrm{kg})$ only on $P$. glabra at Site 2 and $\mathrm{Cr}(2.37 \mathrm{mg} / \mathrm{kg})$ was found on the leaves of $S$. asoca at Site 1. The heavy metal dust deposited on the leaf surface was probably due to vehicular emission and other anthropogenic activities. The analysis showed that all the selected tree species acted as a biomonitor and should be grown that may help to improve the air quality of the area.
\end{abstract}

Keywords: Biomonitoring, Correlation, Deposition, Heavy metals, Species

\section{INTRODUCTION}

Heavy metals are one of the major sources of pollution in the environment due to abrupt changes in agricultural methods, rapid urbanization, industrialization and manmade activities (Kuang et al., 2007; Aprile et al., 2010 and Liu et al., 2016). These pollutants emitted into the ambient air has drastically increased and created severe health hazards to the human population and the other living components of the environment (Zouari et al., 2018). Most of the heavy metals emitted into the atmosphere originate mainly from anthropogenic mobile and stationary sources compared to natural sources. Their concentration was exceeding several times greater than the original emission rate due to bio geochemical cycles. (Kula et al., 2010 and Aslam et al., 2012). Monitoring of heavy metals is most important to assess their distribution with time and locations and take inevitable steps to control or minimize the pollution in the environment (Yildiz et al., 2010).

Monitoring of these heavy metals by equipment posed difficulties by setting an environmental station with skilled technicians and only suitable for some selected areas. Contrarily plants are greatly distributed in remote areas of which some are tolerant of various pollutants, have easy access, are cheaper to monitor and have ease in sampling identified this technique as a very effective one (Ejidike and Onianwa, 2015; Ogunkunle et al., 2015 and Sharma and Uniyal, 2016). Recent investigations like Tilia spp. and Pinus spp. were used for the analysis of heavy metals in the air (Serbula et al., 2013) and Date palm leaves were used for biomonitoring the deposition of atmospheric heavy metal pollutants in Southwestern Iran (Naderizadeh et 
al., 2016) have shown that plants are considered as the effective and the best system for biomonitoring and acting as bioindicators for atmospheric pollutants especially for heavy metals. Biomonitoring by plant species has been carried out in two ways as passive monitoring and active monitoring techniques, first one is by planting or introducing the sensitive plants and the later one is using the plants existing at present in the environment (Nakazato et al., 2018).

Polluted sites specifically with various metal pollutants were monitored frequently by the lower plants such as mosses and lichens due to their more accumulation ability (Jiang et al., 2018 and Yatawara and Dayananda 2019). Nowadays, higher plants (trees) are widely accepted in urban areas with more levels of pollution where mosses and lichens are rarely distributed (Arslan et al., 2009; Khattak and Jabeen, 2012; Deepalakshmi et al., 2014 and Maghakyan et al., 2016).

The absorption, adsorption and accumulation process on the leaves' surface are greater compared than other parts of the plants such as roots, barks and stem. Leaves are sensitive to various air pollutants that show visible changes on their surface depending upon their sensitiveness. The adsorption capacity of the pollutants on their surface or absorption inside the leaves depends upon the size and opening of stomata. The concentration of pollutants can be easily observed from the symptoms and responses shown by the plant species growing in that particular site (Mansour, 2014 and Kaur and Nagpal, 2017).

It has been reported that single species may not act as a suitable bioindicator for monitoring the heavy metal pollution worldwide. Hence, different types of species were identified and used as bioindicators (Coskun 2006). Some of the species, like mosses exhibit their sensitivity towards the single or a mixture of various pollutants (Blagnyte and Paliulis, 2010 and Terpo et al., 2014).

The aim of this work is to analyze the concentration of nine heavy metals as Zinc, Manganese, Lead, Iron, Copper, Chromium, Cadmium, Arsenic and Aluminium deposited on the leaf surface of the five selected tree species such as Sarca asoca (Ashoka), Terminalia catappa (Almond), Ficus religiosa (Peepal), Pongamia glabra (Pongam) and Syzygium cumini (Jamun), growing at different sites of Kanchipuram town. The statistical analysis was carried out to find the significant relationship between different metals. This work was also used to identify species with higher capability to deposition of specific heavy metals on their leaves.

\section{MATERIALS AND METHODS}

\section{Studied plant species}

In the present study, five tree species were ubiquitous at all sampling sites; thus, based on easy availability following trees were shortlisted to have a representative sample from all studied sites.

1. S. asoca - It is an evergreen tree growing up to $9 \mathrm{~m}$ with existence in different parts of India. Leaves are dark green with 30 to $60 \mathrm{~cm}$ long, rigidly subcoriaceous and oblong.

2. T. catappa - It is a large tree found in tropical areas. This deciduous tree grows up to $35 \mathrm{~m}$ tall. The tree has broad leaves with a size of $10-14 \mathrm{~cm}$ width and $15-25 \mathrm{~cm}$ long in egg-shaped with the narrower end at the base arranged in close spirals that fall in the dry season. Their leaves are leathery and glossy dark green.

3. F. religiosa - It is an evergreen or deciduous tree that grows up to a height of $20 \mathrm{~m}$. Leaves are simple, stout, articulated, glabrous, shining, coriaceous, dark green in colour and size $7.5-10 \mathrm{~cm}$ long.

4. P. glabra - It is a fast-growing deciduous tree found up to the height of $25 \mathrm{~m}$. Leaves are small, caducous, oblong, glabrous, and chartaceous. It has deep green leaflets of $5-9 \mathrm{~cm}$.

5. Sy. cumini - It is an evergreen tree up to $25 \mathrm{~m}$ in height. The leaves are simple, smooth, glossy, leathery and elliptic to oblong or ovate shape with 5$10 \mathrm{~cm}$ in length.

All the selected five species are commonly found in all sites chosen for the present work.

\section{Study area}

Kanchipuram is a temple city that is $72 \mathrm{~km}$ away from Chennai, the capital of Tamil Nadu. The city covers an area of $11.605 \mathrm{~km}^{2}$ and its population as per the census carried out in 2011 was $1,64,265$. Kanchipuram is located at $12.8387^{\circ} \mathrm{N}$ and $79.7016^{\circ} \mathrm{E}$ on the banks of the Vegavathi River, a tributary of the Palar river and its elevation is $83.2 \mathrm{~m}$ above sea level (https:// en.wikipedia.org/wiki/Kanchipuram). Kanchipuram is very famous for silk weaving and many varieties of silk sarees are available. Hence it is named silk city. Nowadays, the city's population is significantly increasing in urban areas due to various reasons like it is nearer to Chennai, moderate cost of living, and many industries.

\section{Sampling sites}

The samples were collected during the months of February - March 2019 from six different sites in Kanchipuram town of Tamil Nadu in a distributed form as Industrial area, Institutional area, sensitive zone, high-density traffic area, commercial area and habitat area are given in Table 1.

Site 1, Pallavarmedu has more number of houses, large park, movement of four wheelers are less and 1.7 $\mathrm{km}$ from the bus stand hence it was taken as a control site, site 2 is located with CSI hospital and Government hospital, $0.35 \mathrm{~km}$ away from the bus stand and is the route for buses to reach the outer periphery of the 
Ramesh, S. and Gopalsamy, S. / J. Appl. \& Nat. Sci. 13(3), 1011 - 1019 (2021)

Table 1. Sampling sites of the area of Kanchipuram town selected for the study.

\begin{tabular}{|c|c|c|c|c|c|}
\hline \multicolumn{6}{|c|}{ Sampling Sites } \\
\hline S1 (Control) & S2 & S3 & S4 & S5 & S6 \\
\hline Pallavarmedu & CSI hospital & Moongilmandapam & Collectorate & $\begin{array}{l}\text { Near Cancer } \\
\text { Institute }\end{array}$ & Vella Gate (WG) \\
\hline $\begin{array}{l}\text { Residential } \\
\text { area }\end{array}$ & Sensitive area & Heavy traffic area & $\begin{array}{l}\text { Commercial } \\
\text { area }\end{array}$ & Institutional area & Industrial area \\
\hline
\end{tabular}

town. Site 3 is $0.3 \mathrm{~km}$ from the bus stand and the density of traffic is more since it is the main junction to enter the town. Site 4 is $2 \mathrm{~km}$ away from the bus stand with collector office, police training centers, Archaeological and survey department. Site 5 with Cancer Institute and Bhaktavatsalam Polytechnic College, located on the Chennai-Bangalore National highway and $4 \mathrm{~km}$ from the town. Site 6 with many numbers of rice mills and is located on the Arrokonam-Tirupati state highway.

\section{Sampling}

Ten leaves from all the selected five tree species such as S. asoca, T. catappa, F. religiosa, P. glabra and Sy. cumini were picked up at the height of $1.8 \mathrm{~m}$ to $2.4 \mathrm{~m}$ as per Anicic et al. (2011). The sampling was carried out in the month of February-March 2019 and the fresh leaves were collected in the morning from 6.00 a.m. to 8.00 a.m. It was ensured that there was no precipitation prior for more than 30 days and large amount of dust was deposited on the leaves. The leaves of these species were taken based on their easy availability for the current research work to identify the deposition of heavy metal dust on their leaf surface. These samples were stored in an airtight zip-locked polyethylene bags and taken to the laboratory for experimental analysis of the concentration of heavy metals accumulated on the surface of the leaves. The heavy metals were initially mineralized by closed vessel microwave digestion process and analyzed by using Inductively coupled mass spectrometry (ICPMS) (Galea et al., 2015).

\section{Statistical analysis}

Descriptive statistical analysis was carried out for the heavy metals sampled from six sites of five species and Pearson's correlation coefficient and regression analysis was found out by using SPSS version 18.0 software.

\section{RESULTS AND DISCUSSION}

The results obtained from the experimental analysis showed a widespread pattern of heavy metals in the ambient air and the deposition capacity of metals varied with samplings such as time and method of collection, sites and species. The mean, median, minimum and maximum values of six metals such as $\mathrm{Fe}, \mathrm{Pb}, \mathrm{Zn}$, $\mathrm{Al}, \mathrm{Cr}$ and $\mathrm{Mn}$ and that of other metals $\mathrm{Cu}, \mathrm{Cd}$ and $\mathrm{As}$ concentrations as nil in all the selected five species are mentioned in Table 2.

The sources of the heavy metals like $\mathrm{Pb}$ and $\mathrm{Zn}$ released from traffic, wear and tear of vehicle tires and abandoned automobile parts have been described (Norouzi et al., 2015 and Naderizadeh et al., 2016). Mn in the air originated from the soil, Fe emitted into the air both from natural and anthropogenic sources (Yildiz et al., 2010; Ugulu et al., 2012 and Maghakyan et al., 2016). Cr originated from motor vehicles. Cu due to the combustion of coal and heavy traffic (Liu et al., 2017). There was some variation in the concentration of few heavy metals in all the tree species. Fe in $\mathrm{S}$. asoca varied between 12.73 to $235.533 \mathrm{mg} / \mathrm{kg}$, whereas the range of $0-0,2.39-16.58,3.54-157.91,0-2.37$ and $0-$ $5.61 \mathrm{mg} / \mathrm{kg}$ was observed for $\mathrm{Pb}, \mathrm{Zn}, \mathrm{Al}, \mathrm{Cr}$ and $\mathrm{Mn}$, respectively. In $T$. catappa the range of the heavy metals was $4.29-40.99 \mathrm{mg} / \mathrm{kg}, 0-0,0-2.09,0-76.166,0-0$ and $0-2.76 \mathrm{mg} / \mathrm{kg}$ for $\mathrm{Fe}, \mathrm{Pb}, \mathrm{Zn}, \mathrm{Al}, \mathrm{Cr}$ and $\mathrm{Mn}$, respectively. In $F$. religiosa the concentration of heavy metals ranged as 3.35-104.5, 0-0, 4.95-17.34, 3.96122.5, 0-0 and 0-5.43 mg/kg for $\mathrm{Fe}, \mathrm{Pb}, \mathrm{Zn}, \mathrm{Al}, \mathrm{Cr}$ and $\mathrm{Mn}$, respectively. In $P$. glabra the maximum and minimum values of heavy metals laid between 6.65 to $85.82 \mathrm{mg} / \mathrm{kg}$ for $\mathrm{Fe}$ and 0-185.79, 0-51.12, 0-108.36, 0$0,0-4.85 \mathrm{mg} / \mathrm{kg}$ for $\mathrm{Pb}, \mathrm{Zn}, \mathrm{Al}, \mathrm{Cr}$ and $\mathrm{Mn}$, respectively. The values of heavy metals in Sy. cumini ranged as 14.78-51.54, 0-0, 0-3.46, 6.53-72.98, 0-0 and 0-3.54 $\mathrm{mg} / \mathrm{kg}$ for $\mathrm{Fe}, \mathrm{Pb}, \mathrm{Zn}, \mathrm{Al}, \mathrm{Cr}$ and $\mathrm{Mn}$, respectively. The mean concentration of all the six metals was in the order of $\mathrm{Pb}<\mathrm{Cr}<\mathrm{Mn}<\mathrm{Zn}<\mathrm{Al}<\mathrm{Fe}$ in $\mathrm{S}$. asoca $(0<0.4<$ $2.89<4.4<44.9<85.36)$ and $F$. religiosa $(0<0<$ $0.91<5.08<26.51<37.32), \mathrm{Pb}<\mathrm{Cr}<\mathrm{Mn}<\mathrm{Zn}<\mathrm{Fe}<\mathrm{Al}$ in T.catappa $(0<0<0<0<11.9<23.9)$ and Sy.cumini $(0<0<1.46<1.78<29.02<34.06)$, $\mathrm{Cr}$ $<\mathrm{Mn}<\mathrm{Zn}<\mathrm{Al}<\mathrm{Pb}<\mathrm{Fe}$ in P. glabra $(0<1.17<9.7<$ $23.06<30.97<33.5$ ).

Tiwari et al. (2016) reported the heavy metals such as $\mathrm{Cr}, \mathrm{Cu}, \mathrm{Cd}, \mathrm{Ni}$ and $\mathrm{Pb}$ deposited on the leaves of S.asoca due to high vehicular traffic in Bilaspur city, Chhattisgarh. Patel et al. (2015) investigated the concentration of heavy metals $(\mathrm{Zn}, \mathrm{Pb}, \mathrm{Mn}, \mathrm{Hg}, \mathrm{Cu}, \mathrm{Cr}$, $\mathrm{Cd}, \mathrm{Fe}$ and $\mathrm{As}$ ) deposited on the leaves of $F$. religiosa in the industrial city, Korba, out of which the iron (1700mg/kg) content was more due to coal burning. Agrahari et al. (2018) investigated the lead uptake by F. religiosa from nine sites in Gorakhpur city, Uttar Pra- 
Ramesh, S. and Gopalsamy, S. / J. Appl. \& Nat. Sci. 13(3), 1011 - 1019 (2021)

Table 2. Statistical analysis of heavy metals deposited on the leaves of five species from the sites.

\begin{tabular}{|c|c|c|c|c|c|c|}
\hline Species & Parameters (mg/kg) & Mean & Median & Max & Min & SD \\
\hline \multirow{6}{*}{ S. asoca (Ashoka) } & Iron (Fe) & 85.36 & 66.97 & 235.533 & 12.73 & 85.39 \\
\hline & Lead $(\mathrm{Pb})$ & 0 & 0 & 0 & 0 & 0 \\
\hline & Zinc (Zn) & 4.4 & 2.59 & 16.58 & 2.39 & 6.23 \\
\hline & Aluminium (Al) & 44.9 & 10.95 & 157.91 & 3.54 & 63.03 \\
\hline & Chromium (Cr) & 0.4 & 0 & 2.37 & 0 & 0.97 \\
\hline & Manganese (Mn) & 2.89 & 3.08 & 5.61 & 0 & 1.83 \\
\hline \multirow{6}{*}{ T. catappa (Almond) } & Iron (Fe) & 11.9 & 11.72 & 40.99 & 4.29 & 14.8 \\
\hline & Lead $(\mathrm{Pb})$ & 0 & 0 & 0 & 0 & 0 \\
\hline & Zinc (Zn) & 0 & 0 & 2.09 & 0 & 0.85 \\
\hline & Aluminium (Al) & 23.9 & 18.29 & 76.166 & 0 & 28.1 \\
\hline & Chromium (Cr) & 0 & 0 & 0 & 0 & 0 \\
\hline & Manganese (Mn) & 0 & 0 & 2.76 & 0 & 1.13 \\
\hline \multirow{6}{*}{ F. religiosa (Peepal) } & Iron (Fe) & 37.32 & 28.6 & 104.5 & 3.35 & 39.44 \\
\hline & Lead $(\mathrm{Pb})$ & 0 & 0 & 0 & 0 & 0 \\
\hline & Zinc (Zn) & 5.08 & 2.48 & 17.34 & 4.95 & 6.89 \\
\hline & Aluminium (Al) & 26.51 & 8.6 & 122.5 & 3.96 & 47.66 \\
\hline & Chromium (Cr) & 0 & 0 & 0 & 0 & 0 \\
\hline & Manganese (Mn) & 0.91 & 0 & 5.43 & 0 & 2.22 \\
\hline \multirow{6}{*}{ P. glabra (Pongam) } & Iron (Fe) & 33.5 & 24.87 & 85.82 & 6.65 & 27.32 \\
\hline & Lead $(\mathrm{Pb})$ & 30.97 & 0 & 185.79 & 0 & 75.85 \\
\hline & Zinc (Zn) & 9.7 & 1.03 & 51.12 & 0 & 20.39 \\
\hline & Aluminium (Al) & 23.06 & 8.14 & 108.36 & 0 & 42.02 \\
\hline & Chromium (Cr) & 0 & 0 & 0 & 0 & 0 \\
\hline & Manganese (Mn) & 1.17 & 0 & 4.85 & 0 & 2 \\
\hline \multirow{6}{*}{ Sy. cumini (Jamun) } & Iron (Fe) & 29.02 & 26.02 & 51.54 & 14.78 & 13.68 \\
\hline & Lead $(\mathrm{Pb})$ & 0 & 0 & 0 & 0 & 0 \\
\hline & Zinc $(Z n)$ & 1.78 & 2.35 & 3.46 & 0 & 1.44 \\
\hline & Aluminium (Al) & 34.06 & 30.49 & 72.98 & 6.53 & 24.84 \\
\hline & Chromium (Cr) & 0 & 0 & 0 & 0 & 0 \\
\hline & Manganese (Mn) & 1.46 & 1.19 & 3.54 & 0 & 1.64 \\
\hline
\end{tabular}

desh and they suggested that $F$. religiosa was a suitable bioindicator for the $\mathrm{Pb}$ in air pollution. Tak et al. (2019) analyzed the five heavy metals ( $\mathrm{Zn}, \mathrm{Mn}, \mathrm{Fe}, \mathrm{Cr}$, $\mathrm{Cu}$ ) from the dust deposited on roadside plants ( $F$. religiosa, F. bingolensis, Mangifera indica, Cassia fistula, Alstonia scholaris and Bauhunia variegate) situated on the National highway of Thane, Mumbai city and concluded that the plants were planted along the roadside where the vehicular emission was high.

The present study indicated that the concentrations of heavy metals as $\mathrm{Cu}, \mathrm{Cd}$ and As were below their detectable limit and the values were nil in all the experimental six sites of five species. Fe concentration was found at six sites in five species with wider variations. It was maximum on S.asoca at site 6 , site 2 and $P$. glabra at site 1 (Fig. 1). The maximum concentration may be due to the wear and tear of the vehicles into the atmosphere. Site 2 was more polluted even though it was coming under sensitive area now it had been the major route due to one way under traffic regulation and species exposed were nearer to the road. Deposition of Al was found with higher concentration at site 2 in the leaves of $S$. asoca, $F$. religiosa and $P$. glabra at site 1 on S.asoca and Sy. cumini and at site 6 on T. catappa (Fig. 2). This higher value reflected the more usage of $\mathrm{Al}$, fuel combustion, windblown dust from urban areas, and solid waste disposal related to its production in the mentioned sites selected for this study. Hashimoto et al. (1992) discussed and found that the source for Al in the air was due to human activities. Zn concentration was found high only at site 6 on $P$. glabra due to more vehicle movement, wear and tear of tires, and there was no deposition on $T$. catappa except at site 2 with minimal values (Fig. 3). The concentration of $\mathrm{Mn}$ was low in most of the sites and its deposition was nil on $T$. catappa and $F$. religious at all sites except at site 2 (Fig. 


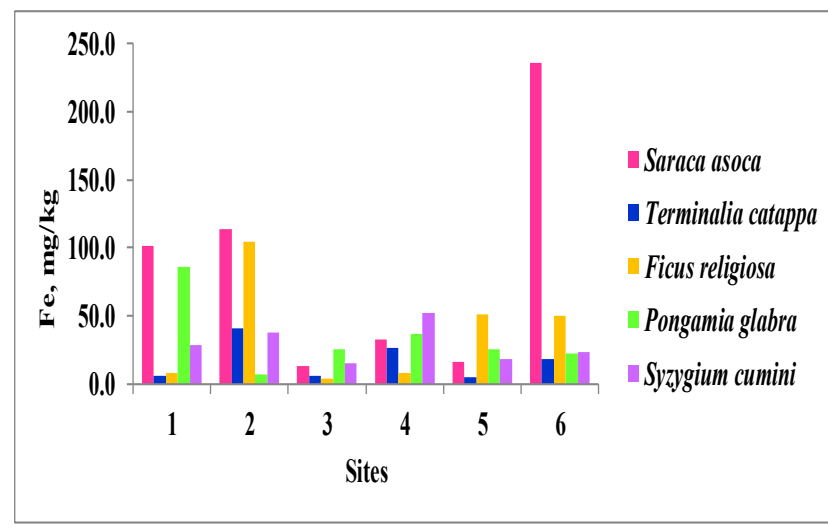

Fig. 1. Fe concentration of the selected sites in five tree species.

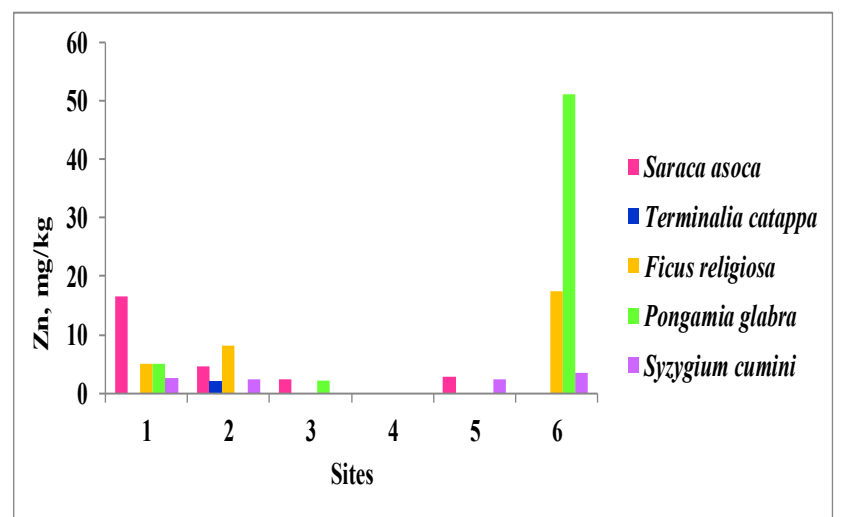

Fig. 3. Zn concentration of the selected Sites in five tree species.

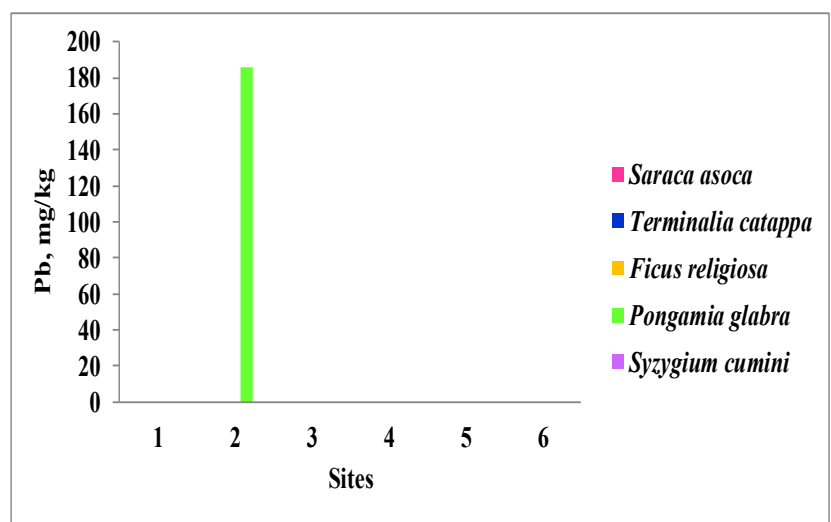

Fig. 5. $P b$ concentration of the selected Sites in five tree species.

4). Lead was deposited with a higher concentration on the leaves of only $P$. glabra in site 2 due to the congestion of vehicles and their values were nil at remaining sites and in the other four species (Fig. 5). Possible remedial measures should be taken to reduce the level of $\mathrm{Pb}$ in site 2 since it is coming under a sensitive zone. Like $\mathrm{Pb}, \mathrm{Cr}$ was also found on $\mathrm{S}$. asoca with lesser concentration only at site 1 (Fig. 6). Even though site 1 was considered the control site, it was also polluted with a higher amount of $\mathrm{Fe}, \mathrm{Al}$, and other metals found with minimal values due to increased

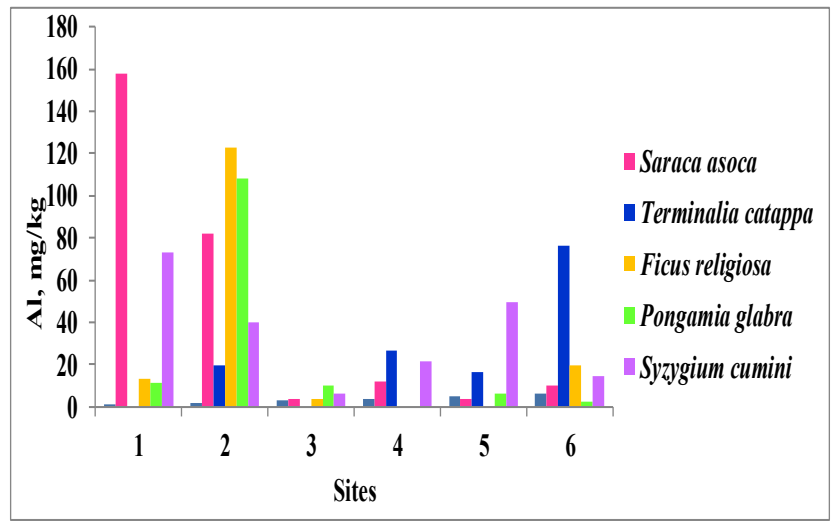

Fig. 2. Al concentration of the selected Sites in five tree species.

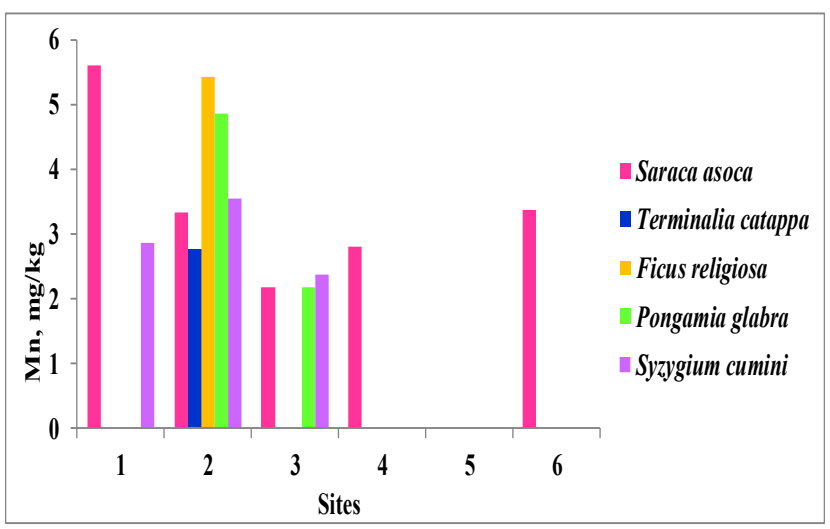

Fig. 4. Mn concentration of the selected Sites in five tree species.

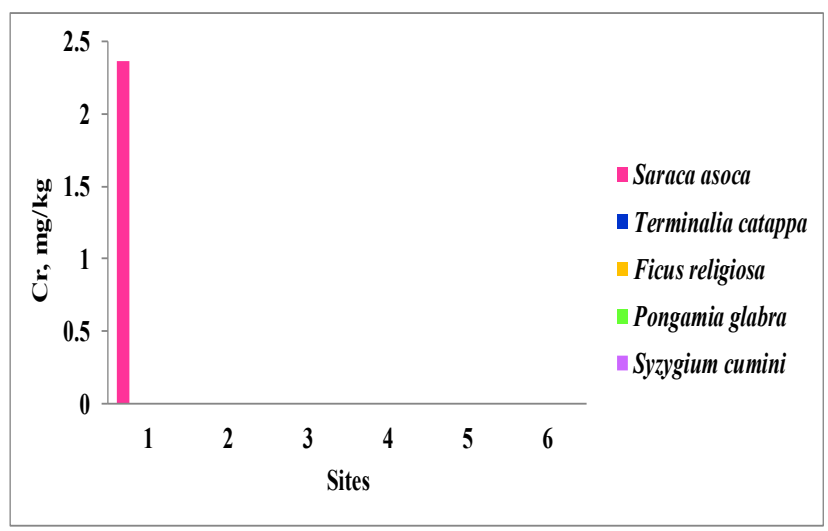

Fig. 6. Cr concentration of the selected Sites in five tree species.

anthropogenic activities and frequent movement of two-wheelers.

The correlation coefficient values (Table 3) and regression equations obtained from the analysis (Table 4 and Fig.7- Fig.11) showed the relationship between the various heavy metals selected from six sites in five species. In S.asoca, Fe had a minimum correlation with $\mathrm{Zn}$, $\mathrm{Al}, \mathrm{Cr}, \mathrm{Mn}$ and no relation with $\mathrm{Pb}$. $\mathrm{Zn}$ had significant correlation with $\mathrm{Al}(\mathrm{r}=0.935)$ and $\mathrm{Cr}(\mathrm{r}=0.959)$, moderate correlation with $\mathrm{Mn}(\mathrm{r}=0.659)$. A high correlation was found in $\mathrm{Al}$ with $\mathrm{Cr}(\mathrm{r}=0.878)$ and $\mathrm{Mn}(\mathrm{r}=0.794) . \mathrm{Cr}$ 
Ramesh, S. and Gopalsamy, S. / J. Appl. \& Nat. Sci. 13(3), 1011 - 1019 (2021)

Table 3. Correlation values of heavy metals deposited on the five species of six sites.

\begin{tabular}{|c|c|c|c|c|c|c|c|}
\hline Species & Parameters & $\mathrm{Fe}$ & $\mathrm{Pb}$ & Zn & Al & $\mathrm{Cr}$ & Mn \\
\hline \multirow{6}{*}{ S.asoca (Ashoka) } & $\mathrm{Fe}$ & 1 &.$a$ & 0.011 & 0.193 & 0.092 & 0.494 \\
\hline & $\mathrm{Pb}$ & &.$a$ &.$a$ &.$a$ &.$a$ &.$a$ \\
\hline & $\mathrm{Zn}$ & & & 1 & 0.935 & 0.959 & 0.659 \\
\hline & $\mathrm{Al}$ & & & & 1 & 0.878 & 0.794 \\
\hline & $\mathrm{Cr}$ & & & & & 1 & 0.730 \\
\hline & $\mathrm{Mn}$ & & & & & & 1 \\
\hline \multirow{6}{*}{ T. catappa (Almond) } & $\mathrm{Fe}$ & 1 & .a & .802 & .296 &.$a$ & .802 \\
\hline & $\mathrm{Pb}$ & &.$a$ &.$a$ &.$a$ &.$a$ &.$a$ \\
\hline & $\mathrm{Zn}$ & & & 1 & -.059 &.$a$ & 1 \\
\hline & $\mathrm{Al}$ & & & & 1 &.$a$ & -.059 \\
\hline & $\mathrm{Cr}$ & & & & &.$a$ &.$a$ \\
\hline & $\mathrm{Mn}$ & & & & & & 1 \\
\hline \multirow{6}{*}{ F. religiosa (Peepal) } & $\mathrm{Fe}$ & 1 & .a & .453 & .845 &.$a$ & .835 \\
\hline & $\mathrm{Pb}$ & &.$a$ &.$a$ &.$a$ &.$a$ &.$a$ \\
\hline & $\mathrm{Zn}$ & & & 1 & .364 &.$a$ & .222 \\
\hline & $\mathrm{Al}$ & & & & 1 &.$a$ & .987 \\
\hline & $\mathrm{Cr}$ & & & & & &.$a$ \\
\hline & $\mathrm{Mn}$ & & & & & & 1 \\
\hline \multirow{6}{*}{ P. glabra (Pongam) } & $\mathrm{Fe}$ & 1 & -.481 & -.112 & -.430 &.$a$ & -.544 \\
\hline & $\mathrm{Pb}$ & & 1 & -.233 & .995 &.$a$ & .900 \\
\hline & $\mathrm{Zn}$ & & & 1 & -.269 &.$a$ & -.312 \\
\hline & $\mathrm{Al}$ & & & & 1 &.$a$ & .916 \\
\hline & $\mathrm{Cr}$ & & & & &.$a$ &.$a$ \\
\hline & $\mathrm{Mn}$ & & & & & & 1 \\
\hline \multirow{6}{*}{ Sy.cumini (Jamun) } & $\mathrm{Fe}$ & 1 & .a & -.259 & .047 &.$a$ & -.038 \\
\hline & $\mathrm{Pb}$ & & .a &.$a$ &.$a$ &.$a$ &.$a$ \\
\hline & $\mathrm{Zn}$ & & & 1 & .446 &.$a$ & -.003 \\
\hline & $\mathrm{Al}$ & & & & 1 &.$a$ & .323 \\
\hline & $\mathrm{Cr}$ & & & & &.$a$ &.$a$ \\
\hline & $\mathrm{Mn}$ & & & & & & 1 \\
\hline
\end{tabular}

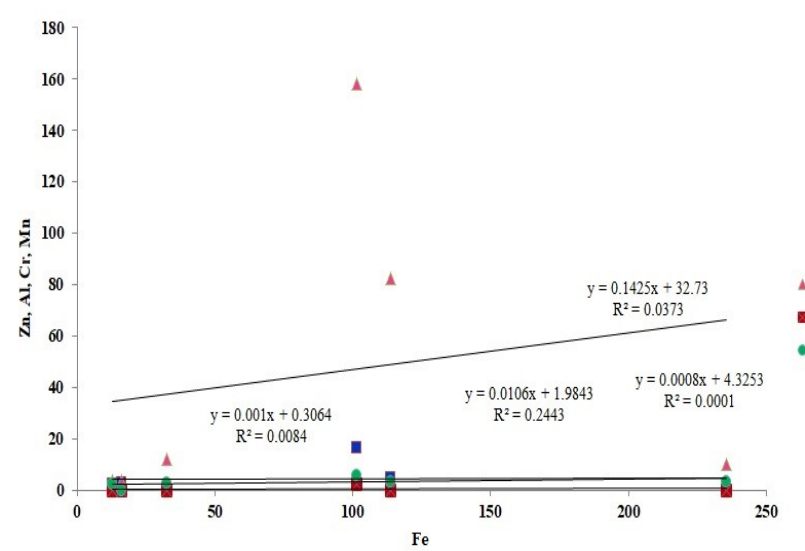

Fig. 7. Regression equation for Fe $\mathrm{Vs} \mathrm{Zn}, \mathrm{Al}, \mathrm{Cr}, \mathrm{Mn}$ in $\mathrm{S}$. asoca.

was positively correlated with $\mathrm{Mn}(\mathrm{r}=0.730)$ (Fig. 7). In T. catappa $\mathrm{Fe}$ was significantly correlated with $\mathrm{Zn}$ $(r=0.802)$ and $\mathrm{Mn}(r=0.802)$, positive correlation with Al. $\mathrm{Zn}$ was negatively correlated with $\mathrm{Al}$ and $\mathrm{Al}$ was negatively correlated with Mn. Other metals were not corre-

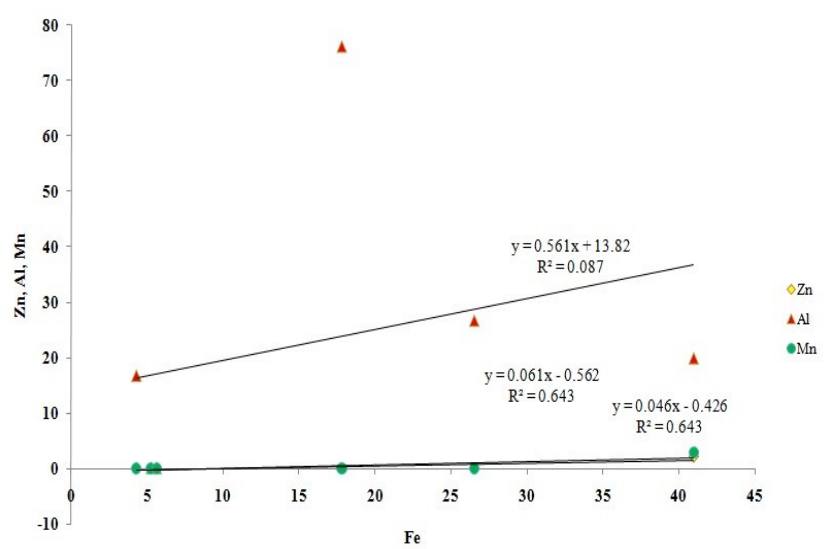

Fig. 8. Regression equation for $\mathrm{Fe} \mathrm{Vs} \mathrm{Zn}, \mathrm{Al}, \mathrm{Cr}, \mathrm{Mn}$ in T.catappa.

lated with any other (Fig. 8). In F. religiosa, Fe was significantly correlated with $\mathrm{Al}(\mathrm{r}=0.845), \mathrm{Mn}(\mathrm{r}=0.835)$ and a positive correlation with $\mathrm{Zn}$ and no correlation with other metals. $\mathrm{Zn}$ was positively correlated with $\mathrm{Al}$ and $\mathrm{Mn}$. Al was significantly related to $\mathrm{Mn}$ ( $\mathrm{r}=0.987$ ) (Fig. 9). 


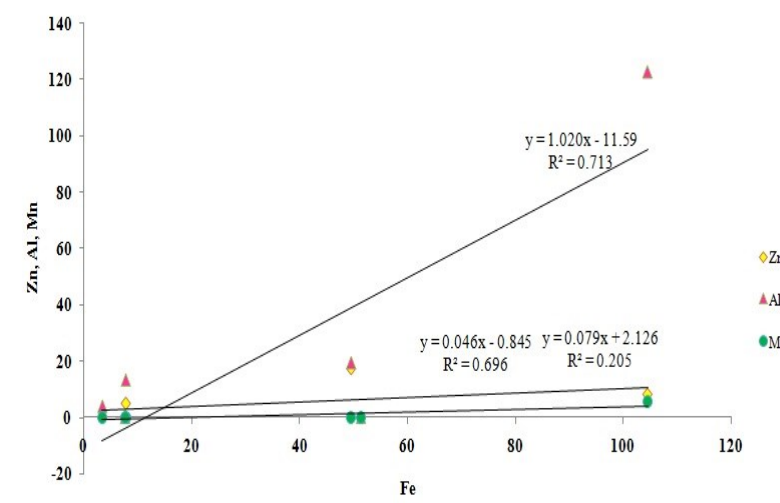

Fig. 9. Regression equation for Fe Vs Zn, Al, Cr, Mn in F. religiosa.

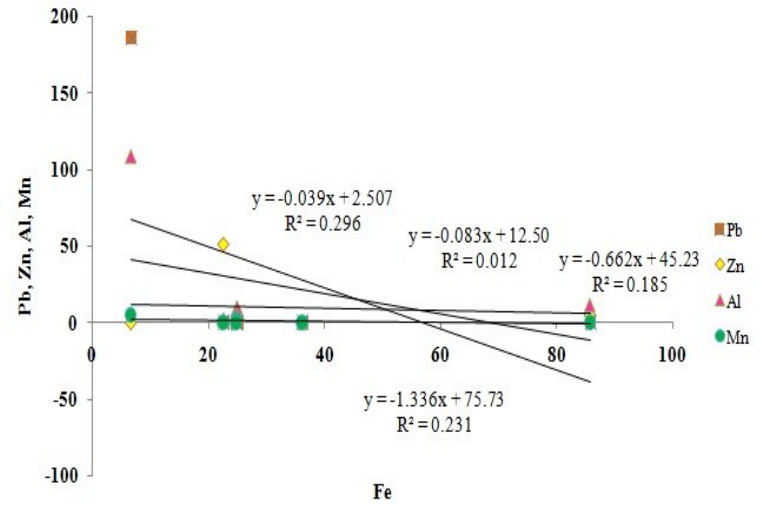

Fig. 10. Regression equation for Fe $\mathrm{Vs} \mathrm{Zn}, \mathrm{Al}, \mathrm{Cr}, \mathrm{Mn}$ in P. glabra.

Table 4. Regression equations of heavy metals depoSited on five species of six sites.

\begin{tabular}{|c|c|c|c|}
\hline Species & Parameters & $Y=a x+b$ & $\mathbf{R}^{2}$ \\
\hline \multirow{4}{*}{ S.asoca (Ashoka) } & $\mathrm{Fe} \mathrm{Vs} \mathrm{Zn}$ & $Y=0.000 x+4.325$ & 0 \\
\hline & $\mathrm{Fe} \mathrm{Vs} \mathrm{Al}$ & $Y=0.142 x+32.73$ & 0.037 \\
\hline & $\mathrm{Fe} \mathrm{Vs} \mathrm{Cr}$ & $Y=0.001 x+0.306$ & 0.008 \\
\hline & $\mathrm{Fe} \mathrm{Vs} \mathrm{Mn}$ & $Y=0.010 x+1.984$ & 0.244 \\
\hline \multirow{3}{*}{ T. catappa (Almond) } & $\mathrm{Fe} \mathrm{Vs} \mathrm{Zn}$ & $Y=0.046 x-0.426$ & 0.643 \\
\hline & $\mathrm{Fe} \mathrm{Vs} \mathrm{Al}$ & $Y=0.561 x+13.82$ & 0.087 \\
\hline & $\mathrm{Fe} \mathrm{Vs} \mathrm{Mn}$ & $Y=0.061 x-0.562$ & 0.643 \\
\hline \multirow{4}{*}{ F. religiosa (Peepal) } & $\mathrm{Fe} \mathrm{Vs} \mathrm{Zn}$ & $Y=0.079 x+2.126$ & 0.205 \\
\hline & $\mathrm{Fe} \mathrm{Vs} \mathrm{Al}$ & $Y=1.020 x-11.59$ & 0.713 \\
\hline & $\mathrm{Fe} \mathrm{Vs} \mathrm{Mn}$ & $Y=0.046 x-0.845$ & 0.696 \\
\hline & $\mathrm{Fe} \mathrm{Vs} \mathrm{Pb}$ & $Y=-1.336 x+75.73$ & 0.231 \\
\hline \multirow{3}{*}{ P. glabra (Pongam) } & $\mathrm{Fe} \mathrm{Vs} \mathrm{Zn}$ & $Y=-0.083 x+12.50$ & 0.012 \\
\hline & $\mathrm{Fe} \mathrm{Vs} \mathrm{Al}$ & $Y=-0.662 x+45.23$ & 0.185 \\
\hline & $\mathrm{Fe} \mathrm{Vs} \mathrm{Mn}$ & $Y=-0.039 x+2.507$ & 0.296 \\
\hline \multirow{3}{*}{ Sy.cumini (Jamun) } & $\mathrm{Fe} \mathrm{Vs} \mathrm{Zn}$ & $Y=-(0.027 x)+2.573$ & 0.067 \\
\hline & $\mathrm{Fe} \mathrm{Vs} \mathrm{Al}$ & $Y=0.084 x+31.59$ & 0.002 \\
\hline & $\mathrm{Fe} \mathrm{Vs} \mathrm{Mn}$ & $Y=-(0.004 x)+1.595$ & 0.001 \\
\hline
\end{tabular}

In $P$. glabra Fe was negatively correlated with $\mathrm{Pb}, \mathrm{Zn}$, $\mathrm{Al}$ and $\mathrm{Mn}$. $\mathrm{Pb}$ showed a significant correlation with $\mathrm{Al}$ $(r=0.995)$ and $\mathrm{Mn}(\mathrm{r}=0.900)$ and negatively with $\mathrm{Zn}$. Al was highly related to $\mathrm{Mn}(\mathrm{r}=0.916)$. There was no correlation between heavy metals and $\mathrm{Cr}$ (Fig. 10). In Sy.cumini $\mathrm{Fe}$ showed a negative correlation with $\mathrm{Zn}$ and $\mathrm{Mn}$ and slightly correlated with $\mathrm{Al}$. Zn had a positive correlation with $\mathrm{Al}$ and negatively with $\mathrm{Mn}$. $\mathrm{Al}$ had weak relation with $\mathrm{Mn}$ (Fig. 11). $\mathrm{Fe}, \mathrm{Al}, \mathrm{Zn}, \mathrm{Mn}$ and $\mathrm{Cr}$ were positive and significantly correlated, showing that there may be a common source for their occurrence and influenced by industrial activities and dense traffic. The results obtained from the regression analysis showed a positive correlation with the metals. Liu et al. (2016) measured the concentration of six heavy metals such as $\mathrm{Zn}, \mathrm{Pb}, \mathrm{Ni}, \mathrm{Cu}, \mathrm{Cr}$, $\mathrm{Cd}$ in moss samples,

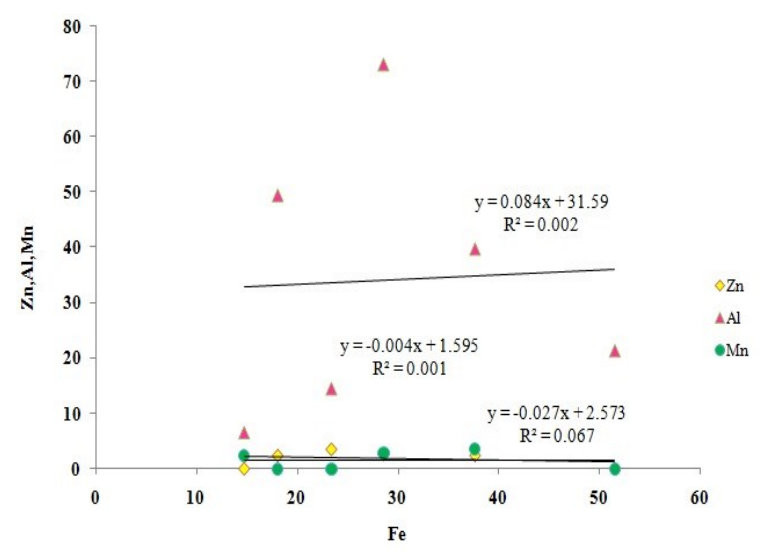

Fig. 11. Regression equation for $\mathrm{Fe} \mathrm{Vs} \mathrm{Zn}, \mathrm{Al}, \mathrm{Cr}, \mathrm{Mn}$ in Sy.cumini. 
Xuzhou city, China, identified that certain heavy metals had a significant correlation between them and suggested that these pollutants were emitted from identical sources.

\section{Conclusion}

The tree species such as S. asoca, T. catappa, Sy. cumini, $F$. religiosa and $P$. glabra for biomonitoring of heavy metals like $\mathrm{Fe}, \mathrm{Pb}, \mathrm{Cu}, \mathrm{Zn}, \mathrm{Al}, \mathrm{Cd}, \mathrm{As}, \mathrm{Cr}$ and $\mathrm{Mn}$ in the ambient air and adopted with all selected sites indicated the significant differences in the levels of deposition of these metals. The metals such as $\mathrm{Cu}, \mathrm{Cd}$ and As were below their detectable limits. $\mathrm{Pb}$ was only found on $P$. glabra and $\mathrm{Cr}$ with a minimum concentration of $2.37 \mathrm{mg} / \mathrm{kg}$ on $\mathrm{S}$. asoca. The deposition of $\mathrm{Fe}$ (235.53-3.35 mg/kg) and Al (157.91-0 mg/kg) was found higher than other metals and was deposited on all the species with varying concentrations. Of all the selected tree species $S$. asoca acted as a better bio monitor for the heavy metals and other species viz. $T$. catappa, Sy. cumini, F. religiosa and P. glabra also showed a good response. Due to higher traffic and other anthropogenic activities, the deposition of pollutants was more in the sensitive areas and near industrial areas than in other selected sites. Thus, all the five tree species were good biomonitors and should be grown to maintain the green belt around the industries and improve the quality of air in the environment.

\section{Conflict of interest}

The authors declare that they have no conflict of interest.

\section{REFERENCES}

1. Agrahari, P., Richa, R., Swati K., Supriya, R., Singh V.K. \& Singh D.K. (2018). Ficus religiosa Tree leaves as bioindicators of heavy metals in Gorakhpur city, Uttar Pradesh, India. Pharmacognosy Journal, 10(3), 416-420. DOI: http://dx.doi.org/10.5530/pj.2018.3.68

2. Anicic, M., Spasic, T., Tomasevic, M., Rajsic, S. \& Tasic, M. (2011). Trace elements accumulation and temporal trends in leaves of urban deciduous trees (Aesculus hippocastanum and Tilia spp.), Ecological Indicators, 11(3), 824-830. https://doi.org/10.1016/j.ecolind.2010.10.009.

3. Aprile, G.G., Di Salvatore, M., Carratu, G., Mingo, A. \& Carafa, A.M. (2010). Comparison of the suitability of two lichen species and one higher plant for monitoring airborne heavy metals, Environmental Monitoring and Assessment, 162, 291- 299. https://doi.org/10.10 07/s10661-009-0796-x.

4. Arslan, H., Guleryuz, G., Leblebici, Z., Kirmizi, S. \& Aksoy, A. (2009). Verbascum bombyciferum Boiss. (Scrophularia ceae) as possible bio-indicator for the assessment of heavy metals in the environment of Bursa, Turkey. Environmental Monitoring and Assessment, 163, 105-113. https://doi.org/10.1007/s10661-009-0820-1.
5. Aslam, M., Verma, D.K., Dhakerya, R., Rais, S., Alam, M. \& Ansari, F.A. (2012). Bioindicator: A Comparative study on uptake and accumulation of heavy metals in some plant's leaves of M.G. Road, Agra City, India. Research Journal of Environmental and Earth Sciences, 4(12), 1060- 1070.

6. Blagnyte, R. \& Paliulis, D. (2010). Research into heavy metals pollution of atmosphere applying moss as bioindicator: a Literature Review, Environmental Research, Engineering and Management, 4(54), 26-33.

7. Coskun, M. (2006). Toxic metals in the Austrian pine (Pinus nigra) bark in the Thrace region, Turkey. Environmental Monitoring and Assessment, 121, 173-179.

8. Deepalakshmi, A. P., Ramakrishnaiah, H., Ramachandra, Y. L. \& Naveen Kumar, N. (2014). Leaves of higher plants as indicators of heavy metal pollution along the Urban roadways, International Journal of Science and Technology, 3(6), 340-346.

9. Ejidike, I.P. \& Onianwa, P.C (2015). Assessment of trace metals concentration in tree barks as indicator of atmospheric pollution within Ibadan city, South-West, Nigeria. Journal of Analytical Methods in Chemistry, 1-8. https:// doi.org/10.1155/2015/243601.

10. Galea, C., Hancu, G., Csiszer, A., Jeszenszky, C.M. \& Barabas, E. (2015). Determination of mineral element content of Pelargonium roseum plant by ICP-MS, Macedonian pharmaceutical bulletin, 61(1), 27- 34.

11. Hashimoto, Y., Sekine, Y., \& Otoshi, T.(1992). Atmospheric aluminum from human activities. Atmospheric Environment. Part B. Urban Atmosphere, 26(3), 295 -300. do i:10.1016/0957-1272(92)90005-d. https://en.wikipedia.org/ wiki/Kanchipuram.

12. Jiang, Y., Fan, M., Hu, R., Zhao, J. \& Wu, Y. (2018). Mosses are better than leaves of vascular plants in monitoring atmospheric heavy metal pollution in Urban areas, International Journal of Environmental Research and Public Health, 15(6), 1-13. DOI: http://dx.doi.org/10.3390/ijer ph15061105.

13. Kaur, M. \& Nagpal, A.K (2017). Evaluation of air pollution tolerance index and anticipated performance index of plants and their application in development of green space along the urban areas. Environmental Science and Pollution Research, 24, 18881-18895. DOI: 10.1007/s11356-017-9500-9.

14. Khattak, M.I. \& Jabeen, R. (2012). Detection of heavy metals in leaves of melia azedarach and Eucalyptus citriodora as biomonitring tools in the region of quetta valley, Pakistan Journal of Botany, 44(2) , 675- 681.

15. Kuang, Y.W., Zhou, G.Y., Wen, D.Z. \& Liu, S.Z. (2007). Heavy metals in bark of Pinus massoniana (Lamb.) as an indicator of atmospheric deposition near a smeltery at Qujiang, China. Environmental Science and Pollution Research, 14(4), 270- 275. DOI: https://doi.org/10.1065/ espr2006.09.344.

16. Kula, I., Yildiz D., Dogan Y., Ay, G. \& Baslar, S. (2010). Trace element contents in plants growing at Mt. Akdag, Denizli. Biotechnology \& Biotechnological Equipment, 24 (1), 1587-1591. https://doi.org/10.2478/V10133-010-0010 $-X$.

17. Liu, C., Zhou, P. \& Fang, Y. (2016). Monitoring airborne heavy metal using mosses in the city of Xuzhou, China. 
Bulletin of Environmental Contamination and Toxicology, 96, 638-644.

18. Liu, Y., Yang, Z., Zhu, M. \& Yin, J. (2017). Role of plant leaves in removing airborne dust and associated metals on Beijing roadsides. Aerosol and Air Quality Research, 17, 2566-2584. DOI: 10.4209/aaqr.2016.11.0474

19. Maghakyan, N., Tepanosyan, G., Belyaeva, O., Sahakyan, L. \& Saghatelyan, A. (2016). Assessment of pollution levels and human health risk of heavy metals in dust deposited on Yerevan's tree leaves (Armenia), Acta Geochimica, 36(1), 16-26. DOI: https://doi.org/10.1007/s11631 $-016-0122-6$

20. Mansour, R. S. (2014). The pollution of the tree is left with heavy metal in Syria. International Journal of Chem Tech Research, 6(4), 2283-2290.

21. Naderizadeh, Z., Khademi, H. \& Ayoubi, S. (2016). Biomonitoring of atmospheric heavy metals pollution using dust deposited on date palm leaves in southwestern Iran. Atmosfera, 29(2), 141- 155. DOI:10.20937/ATM.201 6.29.02.04.

22. Nakazato, R.K., Esposito, M.P., Cardoso-Gustavson, P., Bulbovas, P., Pedroso, A.N.V., de Assis, P.I.L.S. \& Domingos M. (2018). Efficiency of biomonitoring methods applying tropical bioindicator plants for assessing the phytoxicity of the air pollutants in SE, Brazil. Environmental Science and Pollution Research, 25, 19323-19337. https://doi.org/10.1007/s11356-018-2294-6.

23. Norouzi, S., Khademi, H., Faz Cano, A. \& Acosta J.A. (2015). Using plane tree leaves for biomonitoring of dust borne heavy metals: A case study from Isfahan, Central Iran, Ecological Indicators, 57, 64-73. DOI: https://doi.o rg/10.1016/j.ecolind.2015.04.011.

24. Ogunkunle, C.O., Suleiman, L.B., Oyedeji, S., Awotoye, O.O. \& Fatoba, P.O. (2015), Assessing the air pollution tolerance index and anticipated performance index of some tree species for biomonitoring environmental health, Agroforestry Systems, 89(3), 447-454. http://dx.doi.or g/10.1007/s10457-014-9781-7.

25. Patel, K.S., Sharma, R., Dahariya, N.S, Yadav, A., Blazhev, B, Matini, L. \& Hoinkis J. (2015). Heavy Metal Contamination of Tree Leaves, American Journal of Analytical Chemistry, 6(8), 687 - 693. DOI: http://dx.doi.org/10.4236/ ajac.2015.68066.

26. Serbula, S.M., Kalinovic, T.S., Ilic, A.A., Kalinovic, J.V. \&
Steharnik M.M. (2013). Assessment of airborne heavy metal pollution using Pinus spp. and Tilia spp, Aerosol and Air Quality Research, 13, 563 - 573. DOI: 10.4209/ aaqr.2012.06.0153.

27. Sharma, A. \& Uniyal, S.K. (2016). Heavy metal accumulation in Pyrrosia flocculosa (D. Don) Ching growing in sites located along a vehicular disturbance gradient, Environmental Monitoring and Assessment, 188(547), 1-12. https://doi.org/10.1007/s10661-016-5561-3.

28. Tak,A.A. \& Kakde, U.B. (2019). Evaluation of trace elements and particulate matter deposition on plant foliage exposed to vehicular pollution, Acta Botanica Croatica, 78 (2), 164-168. DOI: 10.2478/botcro-2019-0014.

29. Terpo,M., Vasjari, M., Mano, R., Como, M. \& Agoll, M. (2014). Trace element accumulation in the moss Pseudoscleropodium purum in South Albania, Albanian Journal of Agricultural Sciences, Special edition, 201-205.

30. Tiwari, S. \& Pandey, S.K. (2016). Biomonitoring of toxic metals through roadside vegetation exposed to vehicular pollution in Bilaspur city, Environmental Skeptics and Critics, 5(3) pp 57- 62.

31. Ugulu, I., Dogan, Y., Baslar, S. \& Varol, O. (2012), Biomonitoring of trace element accumulation in plants growing at Murat Mountain, International Journal of Environmental Science and Technology, Vol. 9, pp 527- 534. DOI: https://doi.org/10.1007/s13762-012-0056-4.

32. Yatawara, M. \& Dayananda, N. (2019). Use of corticolous lichens for the assessment of ambient air quality along rural-urban ecosystems of tropics, a study in Sri Lanka. Environmental Monitoring and Assessment, 191(3), 1-14.

33. DOI: https://link.springer.com/article/10.1007\%2Fs10661019-7334-2.

34. Yildiz, D., Kula, I., Ay, G, Baslar, S. \& Dogan, Y. (2010). Determination of trace elements in the plants of Mt. Bozdag, Izmir, Turkey. Archives of Biological Sciences, 62(3), 731- 738. http://dx.doi.org/10.2298/ABS1003731Y.

35. Zouari, M., Elloumi, N., Mezghani, I., Labrousse, P., Ben Rouina, B., Ben Abdallah, F. \& Ben Ahmed, C. (2018). Physiological evaluation of Apricot (Prunus armeniaca L.) leaves to air pollution for biomonitoring of atmospheric quality, Pollution, 4(4) , 563-570. DOI: 10.22059/poll.20 18.249423.368. 